\title{
KeTtőS IDENTITÁS SZORÍTÁSÁBAN: GRÚZ TANÁROK AZ ÁRNYÉKOKTATÁSBAN
}

\author{
HOLLE ALEXANDRA \\ BCE Politikatudományi Doktori Iskola
}

Magda N. Kobaknidze: Teachers as Tutors: Shadow Education Market Dynamics in Georgia. (CERC Studies in Comparative Education: Vol. 34.) Cham (Switzerland), 2018. Springer. xii + 253 p. ISBN 978-3-319-95915-3 (eBook)

Hogyan alkotják meg szakmai identitásukat és szerepeiket az árnyékoktatás határán tanárként és magántanárként is tevékenykedő pedagógusok? Hogyan viszonyul az árnyékoktatáshoz az állami oktatási rendszer? Hogyan hoznak gazdasági döntéseket, milyen dinamikák müködnek az árnyékoktatás piacán? Milyen hatásokkal bírhat a kiterjedt magántanári gyakorlat az állami oktatási rendszerre, illetve tágabb értelemben az emberi viszonyokra? Többek között ezekre a kérdésekre keresi a választ egy posztszovjet ország, Grúzia (Georgia) vonatkozásában Magda Kobakhidze könyve.

A szerző az árnyékoktatás vizsgálatához szolgáló elméleti keret megalkotásakor (lásd a 3. fejezetet) több diszciplínára is épít. A korábbi munkák e piacot leginkább a neoklasszikus közgazdaságtan szemüvegén keresztül vizsgálták, és föként a tanárok gazdasági motivációira, valamint a korrupciós kockázatra helyezték a hangsúlyt. Kobakhidze nem szakít e látásmóddal, de a klasszikus közgazdaságtani megközelítés mellett a szociológia és az antropológia jeles képviselőinek - így például Jens Beckertnek, Mark Granovetternek és Stuart Plattnernek - az elméleteit is felhasználja. Egy olyan nézőpontot adaptál, melyben a piaci szereplők nem pusztán a profitmaximalizálásra törekvő racionális aktorok. Motivációik sokrétübbek, hiszen a piac erősen beágyazott egy sajátos társadalmi, kulturális és politikai kontextusba, így működése szempontjából meghatározó szerepe van a társadalmi struktúrának, az erkölcsi normáknak és a hagyományoknak is.

Módszertanát tekintve (lásd a 4. fejezetet) az empirikus munka kvalitatív megközelítésű, mélyinterjúkra épül, törekedve a személyes tapasztalatok és jelentéstartalmak feltárására. A szerző 68 interjút készített tanárokkal - melyek közül néhány logisztikai okokból fókuszcsoportos beszélgetés formájában valósult meg -, illetve további 28-at más érintettekkel: iskolaigazgatókkal, szülőkkel és döntéshozókkal. Bár a könyv fókuszában a tanári perspektíva áll, e megközelítés lehetővé teszi egyéb nézőpontok felvillantását is.

Kobakhidze eredményeinek értelmezéséhez elengedhetetlen a grúz oktatási rendszer sajátosságainak és a tágabb társadalmi kontextusnak az ismerete (lásd a 2. fejezetet). A szovjet érában az oktatási rendszert az erős centralizáció, bürokratikus szemlélet, az autonómia hiánya és ideológiai átitatottság jellemezte. Ugyanakkor a tanári szakmának magas volt a társadalmi presztízse, értelmiségi szerep- 
ként tekintettek rá, valamint az állami oktatásnak is jó volt a percepciója, magas minőségünek érzékelték. Az árnyékoktatás már ekkor is létezett, de kevésbé volt kiterjedt gyakorlat. Ráadásul jóval inkább rejtve volt, mint a későbbiekben, ugyanis létezése nem volt összeegyeztethető a mindenkinek kijáró magas minőségű oktatás üzenetével.

A következő nagyobb korszak az átmenet időszaka. Grúzia 1991-es függetlenné válása után a gazdaság összeomlott, és az oktatásra fordított állami kiadásokat drasztikusan visszavágták, még más posztszovjet országokkal való összehasonlításban is. A GDP-arányos oktatási kiadások az 1991-es hétszázalékos értékről '94-re egy százalék alá csökkentek. A tanári fizetések jelentősen visszaestek, még a létminimum összegét sem érték el, és az oktatás körülményei is romlottak.

$\mathrm{A} z$ átmenet időszakában számos nemzetközi donorszervezet - pl. a Világbank - jelent meg az oktatási szférában, így azt akkoriban a szovjet örökség és a nyugati reformok elegye jellemezte. Jelentős újításokra ekkor azonban még nem került sor, a nagy átalakulás 2001-ben kezdődött. Az oktatási reformok között voltak olyanok, melyek a közvélemény szerint és a hatásvizsgálatok alapján is sikeresnek tekinthetők, de olyanok is, melyek figyelmen kívül hagyták a helyi sajátosságokat. Ráadásul az állandó reformok bizonytalan környezetet teremtettek a tanárok számára. Bár a béreket 2005 óta fokozatosan emelik, továbbra is csak a létminimum közelében vannak, így a tanári állomány elöregedése mellett probléma a pályaelhagyás is. A szakma megítélése kettős: egzisztenciális szempontból alacsony presztízsű, de továbbra is egyfajta tisztelet övezi a tanárokat a társadalomban, így szimbolikus megbecsültsége van.

$\mathrm{A} z$ árnyékoktatás kiterjedt rendszere több tényezőn alapul. A tanárok számára fontos, a megélhetésükhöz szinte nélkülözhetetlen jövedelmi forrás, a családok pedig ezen keresztül kívánják kompenzálni, hogy az állami rendszerben nem jutnak magas minőségü oktatáshoz. Ráadásul a reformok egy része is az árnyékoktatás irányába lökte a szereplőket: a tantervi reformok, a standardizált kimeneti vizsgák bevezetése, valamint az egyetemi felvételik egységesítése olyan elvárásokat teremtettek, melyekre az iskolai oktatás nem készíti fel kellőképpen a diákokat. A diploma magas presztízse miatt a családoknak fontos a továbbtanulás, még úgy is, hogy az országban nem jelentős a diplomás bérelőny. $\mathrm{A} z$ árnyékoktatás tehát kiterjedt jelenséggé vált: a szerző által idézett adatok szerint 2011-ben a 2-11. osztályos diákok negyede, míg a végzős, 12 . osztályos diákok 57 százaléka vett részt ebben a kiegészítő oktatási formában.

Khobakidze kutatásának egyik kérdése, hogy a tanárok szakmai identitása hogyan alakul kettős szerepük tükrében (lásd az 5. fejezetet). Az interjúkból kirajzolódó kép egyértelmü: a pedagógusok számára tanári szerepük a szakmai identitásuk alapja, és sokkal pozitívabban ítélik meg, mint másodlagos - egzisztenciális szempontból ugyanakkor kulcsfontosságú - magántanári szerepüket. Azt, hogy két szerepet kell betölteniük, egyfajta kényszerűségként élik meg, nem pedig valós döntési helyzetként. A magántanári szerep vállalását túlnyomórészt a kereseti lehetőség motiválja, csak kevés interjúalany említette, hogy egyéb belső tényező, például a szakmai fejlődés lehetősége is szerepet játszott volna döntésében. Annak ellenére, hogy a magántanári léthez a gazdasági hasznon túl is tapadnak pozitív élmények (pl. a diákok vizsgákon elért sikere a magántanár számára nemcsak a jól végzett munka bizonyítéka, hanem magas presztízst is biztosít számára a családok körében) az interjúalanyoknál mégis in- 
kább a negatív érzések domináltak. Sokan éreztek lelkiismeretfurdalást amiatt, hogy az iskolai tanári tevékenységükre való felkészülésre, illetve a szakmai továbbképzésre nem tudnak elegendő időt szánni. Emellett féltek attól, hogy diákjaik tanulási motivációját csökkenti, ha ők kevesebb energiát fordítanak a tanári munkára. Ráadásul a szülőktől való anyagi függőséget is negatívan élte meg a többség.

A beszámolókból érdekes kép rajzolódott ki azt illetően, hogy az iskolai oktatás színvonalára hogyan hat az árnyékoktatás. Sok tanár nyíltan vallott arról, hogy a magántanári tevékenysége olyan sok idejét emészti fel, hogy iskolai óráira felkészületlenül érkezik, vagy épp nem ad visszajelzést a diákok házi feladataira. Emellett az időhiány akadályozza az iskola tanárai közötti együttműködést is, illetve oda vezet, hogy a tanárok nem szerveznek extrakurrikuláris tevékenységeket $a z$ iskolában. Mindez nyilvánvalóan negatívan hat az állami oktatás minőségére. Ugyanakkor a tanárok szerint tárgyi tudásuk sokat fejlődik a magánórák tartása során. Ráadásul a két szerep szoros összefonódása miatt nem engedhetik meg maguknak, hogy tanárként ne hozzák az elvárt szakmai színvonalat, hiszen az iskola a magántanítványok rekrutálásának elsődleges helyszíne.

A kutatás arra a kérdésre is kereste a választ, hogy milyen magatartások figyelhetők meg az árnyékoktatás piacán (6. fejezet). A kiélezett versenyben a tanárok többféle stratégiát követnek. Vannak, akik árazási technikákon keresztül, például különféle árengedmények biztosításával kívánják növelni az ügyfélkörüket. Mások stratégiai partnerségre lépnek más tanárokkal, és egyfajta ajánlási rendszert alakítanak ki. Ez nemcsak azt biztosítja, hogy elegendő magántanítványuk legyen, de így elkerülhetik, hogy saját diákjuk váljon a magántanítványukká. Vannak, akik a belső iskolai politikán keresztül kívánnak versenyelőnyhöz jutni, és arra törekednek, hogy a felsőbb (9-12.) osztályokat taníthassák, hiszen ebben a körben nagyobb a kereslet a magántanári szolgáltatásra. $\mathrm{A} z$ interjúkból $\mathrm{az}$ is kiderült, hogy egyes tanárok etikátlan módszereket is bevetnek, és igyekeznek versenytársaikat hitelteleníteni a szülők körében, megkérdőjelezve azok szakmai tudását.

Ugyanez a fejezet foglalkozik a különféle korrupciós kockázatokkal, melyek táptalaja, hogy a tanárok sok esetben saját diákjaikkal foglalkoznak magántanítványként. Ekkor nagy a veszélye, hogy tisztességtelen előnyhöz juttatják őket a többi tanulóval szemben - például a tanórán is favorizálják őket, jobb jegyeket adnak nekik, vagy épp a magánórán átveszik velük az iskolai számonkérés kérdéseit. Bár a tanárok nagy része tisztában van ezekkel a veszélyekkel, és próbálnak is ellenük tenni, úgy vélik, hogy szinte elkerülhetetlen az, hogy magántanítványaik között ne legyen olyan, aki a saját diákjuk. A korrupció egy másik formája, amikor a tanár rábeszéli, valamilyen formán kényszeríti diákját, hogy magánúton is tanuljon nála. Bár a pedagógusok ritkábban számoltak be erről a gyakorlatról, a tíz szülői interjúból nyolcban említették, hogy van rá példa. Vannak olyan esetek is, amikor a korrupciós gyakorlat nem a tanárok, hanem a szülők részéről jelentkezik. Ilyenkor explicit kifejezik, hogy pénzükért cserébe nemcsak oktatást, hanem jó iskolai jegyeket vagy a dolgozatkérdések előzetes ismertetését is elvárják.

A könyv hetedik fejezete az árnyékoktatási piac társadalmi beágyazottságával foglalkozik. Az interjúk alapján egyértelmü, hogy az árakat nemcsak a kereslet és a kínálat viszonya, hanem a társadalmi viszonyrendszerek is befolyásolják. Így például elterjedt gyakorlat, hogy a tanárok rokonaik számára ingyenesen biztosítják 
a magánórákat. Grúziában sokkal kiterjedtebben értelmezik a rokoni kört, mint hazánkban, így ez a gyakorlat sok tanárra túlzott terheket ró, ami többeknek frusztrációt okoz. Ennek ellenére a társadalmi normák, a vélt és valós nyomás miatt nem utasíthatják el a rokon diákokat. Az árnyékoktatási szférában egy másik fontos ingyenes szegmens is létezik: sok magántanár vállalja a rossz anyagi körülmények között élő gyerekek oktatását is. Mivel a magánórák általában kiscsoportos oktatást jelentenek, elterjedt az a gyakorlat, hogy a fizetős diák mellé néhány olyan diákot is beemelnek, akik ezt nem engedhetnék meg maguknak. Mindez egyértelmüvé teszi, hogy a tanárok nem feltétlenül a profitmaximalizálásra törekednek, hanem olyan morális megfontolások is vezetik őket, mint a szolidaritás és a közjó.

A könyv egyik legérdekesebb kérdése, hogy a tanárok és a döntéshozók szükségesnek látják-e az árnyékoktatás piacának szabályozását, adóztatását. Bár mindkét érintett csoport tisztán látja a jelenlegi rendszer negatívumait, melyek a tanárok körében gyakran kellemetlen érzéseket is okoznak, mindkét fél a status quo fenntartása mellett van. A döntéshozók inkább passzív szerepbe süllyednek és elhallgatják a szabályozatlan informális piacot, illetve szemet hunynak felette. A tanárok pedig - bár több szempontból rossznak tartják - megváltoztathatatlannak érzik a kialakult gyakorlatot. Sőt, úgy vélik, hogy ha az állam szabályozóként próbálna fellépni, akkor bizonyára csoportosan emelnék fel a hangjukat, kikényszerítve a politikai meghátrálást. Annak ellenére alakult ki ez a határozott vélemény, hogy a tanári érdekképviseleti szervek kifejezetten gyengék Grúziában.

A könyv számos további részlettel szolgál, de nem csak annak érdemes kézbe vennie, aki mélyebb bepillantást szeretne nyerni a grúz árnyékoktatásba, illetve az azt meghatározó kulturális és történelmi örökségbe, társadalmi viszonyokba. A munka példaértékü abból a szempontból is, hogy több elméleti megközelítést használ, igyekezve kiegészíteni az árnyékoktatás vizsgálatakor dominánsan alkalmazott neoklasszikus közgazdaságtani perspektívát. E szemléletmód alkalmas a jelenség árnyaltabb megközelítésére, és megtermékenyítő lehet a hazai kutatások terén is. Emellett a könyv módszertani szempontból is inspiráló, így mindenkinek ajánlott, aki érdeklődik a kvalitatív kutatási módszerek iránt.

A cikk a Creative Commons Attribution 4.0 International License (https://creativecommons.org/licenses/ by-nc/4.0/) feltételei szerint publikált Open Access közlemény, melynek szellemében a cikk bármilyen médiumban szabadon felhasználható, megosztható és újraközölhető, feltéve, hogy az eredeti szerző és a közlés helye, illetve a CC License linkje és az esetlegesen végrehajtott módosítások feltüntetésre kerülnek. 